\title{
Metered Aerosol Dosage Form
}

National Cancer Institute

\section{Source}

National Cancer Institute. Metered Aerosol Dosage Form. NCI Thesaurus. Code C42960.

An aerosol contained in a device with valves that permits the release of a specified quantity of active and/or inert ing redient(s) upon activation. 